\title{
Immunostimulatory Activity Test of Extract and Isolation of the Secondary Metabolites of Kabau (Archidendron Bubalinum) Fruit Peel
}

\author{
Fauzia Noprima Okta 1,* (D), Sukrasno Sukrasno ${ }^{2}$ (D) Kusnandar Anggadiredja $^{3 \text { (iD }}$ \\ 1 Department of Pharmaceutical Biology, School of Pharmacy, Bandung Institute of Technology, Bandung, Indonesia; \\ fauzianoprima.okta@gmail.com (F.N.O.); \\ 2 Department of Pharmaceutical Biology, School of Pharmacy, Bandung Institute of Technology, Bandung, Indonesia; \\ sukras@fa.itb.ac.id (S.S.); \\ 3 Department of Pharmaceutical Biology, School of Pharmacy, Bandung Institute of Technology, Bandung, Indonesia; \\ kusnandar@fa.itb.ac.id (K.A.); \\ * Correspondence: fauzianoprima.okta@gmail.com (F.N.O.);
}

Received: 20.05.2021; Revised: 15.06.2021; Accepted: 17.06.2021; Published: 24.06.2021

\begin{abstract}
Kabau fruit peel has higher antioxidant activity. Antioxidants can changes immunological and oxidative stress parameters and enhance the immune system. This study aimed to determine the immunostimulatory activity of $96 \%$ and $50 \%$ ethanol extracts of kabau fruit peel and to isolate the major secondary metabolites. The immunostimulatory activity was tested using the carbon clearance method. Eighteen male Swiss Webster mice were divided into groups, given each ethanol extract at a respective dose of 100 and $200 \mathrm{mg} / \mathrm{kg} \mathrm{BW}, 0.5 \% \mathrm{Na}-\mathrm{CMC}$ as the negative control, and $19.5 \mathrm{mg} / \mathrm{kg}$ BW Stimuno as the positive control. Each treatment was given for seven days. The active extract was further fractionated and isolated using chromatography, followed by identification and characterization of the isolate using TLC-Scanner and NMR. The $96 \%$ ethanol extract had immunostimulatory activity, with a phagocytic index of 1.17. Isolation of the ethanol extract revealed Quercitrin, a flavonoid, with Rf value of 0.55 . Results of this study indicate that kabau fruit peel extract has immunostimulatory activity with flavonoid as the active ingredient.
\end{abstract}

Keywords: immunomodulatory; Kabau (Archidendron bubalinum); fruit peel; carbon clearance; flavonoids.

(C) 2021 by the authors. This article is an open-access article distributed under the terms and conditions of the Creative Commons Attribution (CC BY) license (https://creativecommons.org/licenses/by/4.0/).

\section{Introduction}

Immunomodulators have a role in increasing, suppress, or modulate the immune system (adaptive or innate immune system) [1]. A healthy immune system can kill pathogens and tumor cells by identifying and killing foreign materials [2]. The phytochemical compounds of plants can act as an immunomodulator; these include glycosides, flavonoids, alkaloids, phenol, saponins, sterols [3], terpenoid, and coumarin [1]. The flavonoid in the plant has several biological activities, including immunomodulator and antioxidant [4,5]. Polysaccharides from plants also have immunomodulatory and antioxidant activities [6-9].

One of the polyphenol groups, quercetin, has immunomodulatory and antioxidant activity by increasing IFN- $\gamma$ secretion and reducing oxidative stress [10,11]. Cyclophosphamide-induced animals treated with vitamin $\mathrm{C}$ were shown to have improved immunodeficiency as well as oxidative stress parameters [12]. This data shows the relationship between oxidative body status and immune response. 
Kabau (Archidendron bubalinum) is a plant that is closely related to jengkol (Archidendron pauciflorum), a plant with fruits known for its strong aroma. Kabau (A. bubalinum) grows naturally in secondary forests in Sumatra (one of five major islands in Indonesia), Malaysia, and Thailand [13]. Kabau seed is used as a flavoring agent in cooking and traditional vegetable salad. Kabau log is used as construction materials for the construction of houses and household appliances [13].

Kabau seed has the potential as an antioxidant [5]. However, the kabau fruit peel has better antioxidant activity [14]. The phytochemical screening of kabau fruit peel and kabau seed showed the presence of alkaloids, flavonoids, phenols, tannins, terpenoids/steroids, mono/sesquiterpene, saponins, and quinones [14].

This study aimed to determine the immunostimulatory activity of $96 \%$ and $50 \%$ ethanol extracts and to isolate the major secondary metabolites of kabau fruit peel.

\section{Material and Method}

Kabau fruits were collected from Silago, Dharmasraya, West Sumatra. The result of the taxonomic determination in ANDA Herbarium at Andalas University showed that the plants used were kabau (Archidendron bubalinum (jack) I.C. Nielsen). Kabau fruit peels were chopped and then dried at temperature $<50^{\circ} \mathrm{C}$ and subsequently ground to powder.

\subsection{Extraction.}

Extraction was carried out by reflux using $96 \%$ ethanol as the solvent. The residue extraction was further extracted with $50 \%$ ethanol for 2 hours. In total, one kilogram of kabau fruit peel powder was extracted with $2.5 \mathrm{~L}$ of solvent three times. Phytochemical screening was carried out on the crude drug and extracts to determine the secondary metabolites such as alkaloid, flavonoid, phenol, tannin, saponin, quinone, and terpenoid/steroids.

\subsection{Determination of total flavonoid content and total phenol content.}

\subsubsection{Total flavonoid content.}

Determination of total flavonoid content referred to the method by Sujono et al., with slight modification [4]. Extract solution (80 mg extracts diluted in $10 \mathrm{~mL}$ methanol) was prepared in a volume of $0.5 \mathrm{~mL}$. The solution was then mixed, then added with $1.5 \mathrm{~mL}$ methanol, $0.1 \mathrm{~mL}$ of $10 \% \mathrm{AlCl}_{3}, 0.1 \mathrm{~mL}$ of sodium acetate, and $2.8 \mathrm{~mL}$ aqua dest, and incubated at room temperature for $30 \mathrm{~min}$. The absorbance of the final solutions was measured at a wavelength of $425 \mathrm{~nm}$.

\subsubsection{Total phenol content.}

Determination of total phenol content was performed using Folin-Cioucalteu reagent, referred to the method by Yunitrianti et al., with slight modification [15]. Half a milliliter solution ( $80 \mathrm{mg}$ extracts diluted in $10 \mathrm{~mL}$ methanol) was added with $2.5 \mathrm{~mL}$ of $7.5 \%$ FolinCioucalteu reagent and incubated for $8 \mathrm{~min}$. It was then added with $2 \mathrm{~mL}$ of $1 \% \mathrm{NaOH}$ and incubated for $60 \mathrm{~min}$. The absorbance of the final solutions was measured at a wavelength of $730 \mathrm{~nm}$. 


\subsection{Carbon clearance method.}

The carbon clearance test aims to calculate the phagocytic index from the absorbance values of blood samples following administration of Chinese ink through the tail veins [16][17].

\subsubsection{Preparation of test solutions.}

The test solutions were the ethanol extracts at a dose of 100 and $200 \mathrm{mg} / \mathrm{kg} \mathrm{BW}$. The positive control used a Stimuno ${ }^{\circledR}$ capsule was prepared in a suspension in $0.5 \% \mathrm{Na}-\mathrm{CMC}$ to be given at a dose of $19.5 \mathrm{mg} / \mathrm{kg} \mathrm{BW}$. Test solutions were administered once a day for seven days.

\subsubsection{Preparation of animal test.}

Eight-week-old male Swiss Webster mice were obtained from the animal laboratory of the Research and Innovation Center, ITB. Mice were acclimatized for one week before starting the experiment. Mice were kept in a room at $25 \pm 2{ }^{\circ} \mathrm{C}$ with $55-60 \%$ humidity and 12 hours12 hours light-dark cycle. The procedure for animal treatment in experiments has been approved by the Ethics Committee of Padjadjaran University, Bandung (Ethical Approval No.: 141 / UN6.KEP / EC / 2021).

\subsubsection{Carbon clearance measurement.}

Mice were divided into six groups, each receiving vehicle (Na-CMC $0.5 \%$ ), ethanol extracts at a dose of $100 \mathrm{mg} / \mathrm{kg} \mathrm{BW}$ and $200 \mathrm{mg} / \mathrm{kg} \mathrm{BW}$, and Stimuno ${ }^{\circledR}$ suspension, respectively. Following seven days of treatment, initial blood sampling was carried out from the tip of the tail vein. All mice were then injected with Chinese ink at $0.1 \mathrm{~mL} / 10 \mathrm{~g} \mathrm{BW}$ via the tail vein. At the $5^{\text {th }}$ and $20^{\text {th }}$ minutes after carbon injection, $20 \mu \mathrm{l}$ of blood sample was taken and then added to $4 \mathrm{~mL}$ of $1 \%$ acetic acid solution. The final solution was measured for its absorbance using a UV-Vis spectrophotometer at a wavelength of $675 \mathrm{~nm}$. The absorbance values were used to measure the rate of carbon clearance $(k)$ and phagocytic index $(\alpha)$ according to the following formula [17]:

$$
\begin{aligned}
k & =\frac{\operatorname{Ln} O D 5-\operatorname{Ln} O D 20}{t 2-t 1} \\
\alpha & =\sqrt[3]{k} \frac{\text { BodyWeight }}{\text { Liver wt } t \text { spleen } w t},
\end{aligned}
$$

where OD5 and OD20: absorbance of blood sample at $5^{\text {th }}$ and $20^{\text {th }}$ minutes, $t 1$ and $t 2$ : the initial and the last time of blood collection, respectively.

\subsection{Isolation of active compound.}

The active extract showing immunostimulant activity was further fractionated and isolated using chromatography. Fractionation was carried out with vacuum liquid chromatography using a column with a diameter of $10 \mathrm{~cm}$ and a length of $24 \mathrm{~cm}$ with silica gel $60 \mathrm{H}$ as stationary phase. The solvent used as mobile phase for gradient separation is n-hexane, ethyl acetate, and methanol. The mobile phase was used in gradually increasing polarity: nhexane-ethyl acetate (5:5), n-hexane-ethyl acetate (2.5:7.5), $100 \%$ ethyl acetate, ethyl acetatemethanol (9:1) to $100 \%$ methanol with a mobile phase composition is $500 \mathrm{~mL}$. 
The fraction obtained was monitored using thin-layer chromatography (TLC) with silica gel $\mathrm{GF}_{254}$ as stationary phase and n-hexane-ethyl acetate-methanol (2:7.5:0.5) as mobile phase. The TLC plates were sprayed with the citroborate reagent and observed under $366 \mathrm{~nm}$ UV light. Fractions with the same chromatogram pattern were combined and were further fractionated with column chromatography with gradient elution using $100 \mathrm{~mL}$ mobile phase starting from n-hexane-ethyl acetate (2:8) to $100 \%$ methanol. The result of fractionation was monitored using TLC.

The separation of flavonoids was continued with column chromatography using an isocratic mobile phase of $n$-hexane-chloroform-methanol (4:80:20). The subfraction obtained was monitored using TLC with silica gel $\mathrm{GF}_{254}$ as stationary phase and ethyl acetate-methanol (9:1) as mobile phase. The isolate was characterized by a single spot on the TLC plate.

\subsection{Identification and characterization of the isolate.}

TLC-Scanner was used to determine the Rf value and the maximum wavelength of the isolate, which was further characterized and identified using NMR spectroscopy Agilent 500 $\mathrm{MHz}$.

\section{Results and Discussion}

\subsection{Extraction and phytochemical screening.}

Reflux was chosen as an extraction method in this study on the consideration that it can extract more secondary metabolites. Sati et al., demonstrated that reflux produced the highest flavonoid glycosides than soxhlet and maceration [18]. In addition, reflux has been shown to be economical and efficient, which does not require expensive costs for tools, equipment handling, and operating personnel [19]. The yields were $8.5 \%$ and $12.3 \%$ for $96 \%$ and $50 \%$ ethanol extracts, respectively. The $96 \%$ ethanol extract had a blackish-green color with a thick texture, while the $50 \%$ ethanol extract was reddish-brown with a dry texture.

Phytochemical screening of extracts and crude drug of kabau fruit peels were presented in Table 1.

Table 1. Result of phytochemical screening of extracts and crude drug of Kabau fruit peels.

\begin{tabular}{c|c|c|c} 
Group & $\begin{array}{c}\text { Crude } \\
\text { drug }\end{array}$ & $\begin{array}{c}\mathbf{9 6} \% \\
\text { ethanol } \\
\text { extract }\end{array}$ & $\begin{array}{c}50 \% \\
\text { ethanol } \\
\text { extract }\end{array}$ \\
\hline Flavonoid & + & + & + \\
\hline Phenol & + & + & + \\
\hline Alkaloid & - & - & - \\
\hline Tannin & + & + & + \\
\hline Quinon & - & - & - \\
\hline Saponin & + & - & + \\
\hline Terpenoid/Steroid & + & + & + \\
Description: $(+)=$ detected, $(-)=$ not detected
\end{tabular}

\subsection{Total flavonoid content and total phenol content.}

A series of quercetin concentrations $(40,45,50,60$, and $100 \mathrm{ppm})$ was used as a standard. The addition of $0.1 \mathrm{~mL}$ of $10 \% \mathrm{AlCl}_{3}$ produces a yellow complex compound that shifts the wavelength toward visible light, maintained by sodium acetate [4,20]. At $425 \mathrm{~nm}$, the 
quercetin regression equation was found to be $(\mathrm{y})=0.0098 \mathrm{x}-0.1536$, with a correlation coefficient $\left(\mathrm{r}^{2}\right)$ of 0.9983 .

The addition of the Folin-Ciocalteu reagent in phenol determination produced complex blue compounds [20]. A series of gallic acid concentrations used as a standard [21,22]. Upon spectrophotometric measurement of gallic acid in several concentrations (40, 50, 60, 80 and $100 \mathrm{ppm})$, regression equation to be $(\mathrm{y})=0.0069 \mathrm{x}-0.0209$, with a correlation coefficient $\left(\mathrm{r}^{2}\right)$ of 0.9948 .

Results of total flavonoid and phenol content determination are presented in Table 2.

Table 2. Total flavonoid and phenol content of ethanol extracts.

\begin{tabular}{c|c|c} 
Extracts & $\begin{array}{c}\text { Total } \\
\text { Flavonoid } \\
\text { Content } \\
(\boldsymbol{\%})\end{array}$ & $\begin{array}{c}\text { Total Phenol } \\
\text { Content }(\%)\end{array}$ \\
\hline $\begin{array}{c}\mathbf{9 6} \% \\
\text { ethanol } \\
\text { extract }\end{array}$ & $1.850 \pm 0.021$ & $9.507 \pm 0.176$ \\
\hline $\begin{array}{c}\mathbf{5 0} \% \\
\text { ethanol } \\
\text { extract }\end{array}$ & $0.593 \pm 0.002$ & $10.512 \pm 0.071$ \\
\hline
\end{tabular}

The $96 \%$ ethanol extract had the highest flavonoid content, while the total phenol content between the two extracts was not much different.

\subsection{Immunomodulatory test.}

The extracts were subsequently tested for immunostimulatory activity. The activity testing used the carbon clearance method, which can measure the activity of macrophages to clear the foreign material in circulation [16]. The foreign material in this study is represented with Chinese ink. Results of the immunomodulatory test are manifested in the phagocytic index, presented in Table 3.

Table 3. Phagocytic index.

\begin{tabular}{c|c|c} 
Group & $\begin{array}{c}\text { Phagocytic } \\
\text { index }\end{array}$ & Category \\
\hline Stimuno Capsule $19,5 \mathrm{mg} / \mathrm{Kg} \mathrm{BW}$ & 1.4564 & Stimulant \\
\hline Na CMC 0,5 & 1.0000 & - \\
\hline $96 \%$ ethanol extract $100 \mathrm{mg} / \mathrm{kg} \mathrm{BW}$ & 1.1682 & Stimulant \\
\hline $50 \%$ ethanol extract $100 \mathrm{mg} / \mathrm{kg} \mathrm{BW}$ & 0.9754 & Suppressant \\
\hline $96 \%$ ethanol extract $200 \mathrm{mg} / \mathrm{kg} \mathrm{BW}$ & 1.1699 & Stimulant \\
\hline $50 \%$ ethanol extract $200 \mathrm{mg} / \mathrm{kg} \mathrm{BW}$ & 0.9778 & Suppressant
\end{tabular}

The results showed that the reference substance Stimuno ${ }^{\circledR}$ had the highest phagocytic index of 1.4564, while the $96 \%$ ethanol extracts at 100 and $200 \mathrm{mg} / \mathrm{kg}$ BW had phagocytic indices of 1.1682 and 1.1699 , respectively, indicating that these substances fall into the category of immunostimulant and a value of lower than 1, as shown by $50 \%$ ethanol extract is categorized as an immunosuppressant [23].

The phagocytic indices obtained in this study could be correlated with the total flavonoid content in the extracts. We observed that $96 \%$ ethanol extract had higher total flavonoid than $50 \%$ ethanol extract. Zalizar demonstrated that the higher the flavonoid content, the higher the phagocytic capacity and activity. In this study, the escalating doses of $n$-hexane 
extract of Phyllantus niruri produced gradually increasing phagocytic activity upon Staphyloccocus aureus infection [24].

\subsection{Isolation.}

The active extract was further fractionated and isolated using chromatography. The result was a yellow powder isolate, which was further analyzed using TLC scanner to visualize the spectrodensitogram of the spots on the TLC plate.

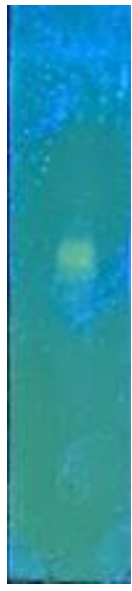

(a)

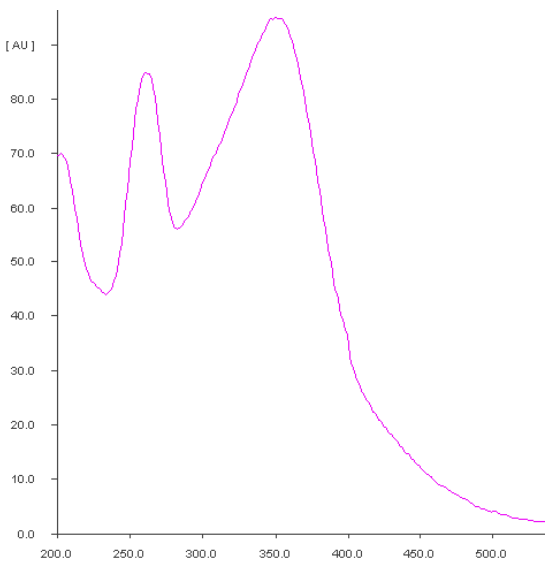

(b)

Figure 1. Thin Layer Chromatography of isolate. The stationary phase was silica gel GF254, with ethyl acetatemethanol-formic acid (9:1:0,05) as mobile phase, (a) plate presentation after spraying with citroborate and viewed under $366 \mathrm{~nm}$ UV light; (b) spectrodensitogram.

As presented in Figure 1, results of TLC-Scanning revealed an Rf value of 0.55 with two peaks in spectrodensitogram at 350 and $262 \mathrm{~nm}$. The result suggested the presence of a flavonoid. The $350 \mathrm{~nm}$ peak might correspond to the cinnamoyl ring, while that of the $262 \mathrm{~nm}$ to the benzoyl ring.

\subsection{Characterization and structure identification of isolate by NMR.}

The yellow powder isolate was identified as Quercitrin, based on the following characteristics: ${ }^{1} \mathrm{H}-\mathrm{NMR}\left(500 \mathrm{MHz}, \mathrm{CD}_{3} \mathrm{OD}\right)$ spectra: 0,93 $(3 \mathrm{H}, \mathrm{d}), 3,3(1 \mathrm{H}, \mathrm{d}), 3,4(1 \mathrm{H}, \mathrm{m})$, 3,7 $(1 \mathrm{H}, \mathrm{dd}), 4,2(1 \mathrm{H}, \mathrm{m}), 5,3(1 \mathrm{H}, \mathrm{d}), 6,2(1 \mathrm{H}, \mathrm{d}), 6,3(1 \mathrm{H}, \mathrm{d}), 6,9(1 \mathrm{H}, \mathrm{d}), 7,31(2 \mathrm{H}, \mathrm{t}) .{ }^{13} \mathrm{C}-$ NMR 125 MHz, CD 3 OD spectra : 17, 6 (C6”), 71,9 (C2”), 72,0 (C3”), 72,1 (C4”), 73,2 (C5”), 94,7 (C8), 99,7 (C6), 103,5 (1’), 105,8 (C10), 116,3 (C5'), 116,9 (C2'), 122,8 (C6'), 122,9 (C1'), 136,2 (C3), 146,4 (C3'), 149,7 (C2), 158,5 (C4'), 159,2 (C9), 163,1 (C5), 165,8 (C7), $179.6(\mathrm{C} 4)$.

Based on ${ }^{1} \mathrm{H}-\mathrm{NMR}$ spectra, as presented in Figure 2, a chemical shift at $0.93 \mathrm{ppm}(3 \mathrm{H}$, d) suggested a methyl group. At a 3.33-4.22 ppm the chemical shift indicated multiple protons in sugar. The chemical shift at $5.34 \mathrm{ppm}$ showed more deshieldings, indicating protons bound to oxygen that connected sugar and flavonoid. The chemical shift of $6.19 \mathrm{ppm}(1 \mathrm{H}, \mathrm{d})$, which was more upfield than the chemical shift of $6.36 \mathrm{ppm}(1 \mathrm{H}, \mathrm{d})$, was estimated to be the proton in $\mathrm{C}-6$, which had one $\mathrm{C}$ neighbor atom, the proton at $\mathrm{C}-8$ at a chemical shift of $6.36 \mathrm{ppm}$. A chemical shift of 6.91-7.31 ppm $(1 \mathrm{H}, \mathrm{d})$ suggested a proton bound to the cinnamoyl ring of the flavonoid, which was more deshielding than the benzoyl ring. The chemical shift of $6.91 \mathrm{ppm}$ 
$(1 \mathrm{H}, \mathrm{d})$ indicated the proton attached to $\mathrm{C}-5$ ', which had one neighboring proton, the proton at C-6'.

Fazia-SF $1 \mathrm{H}$
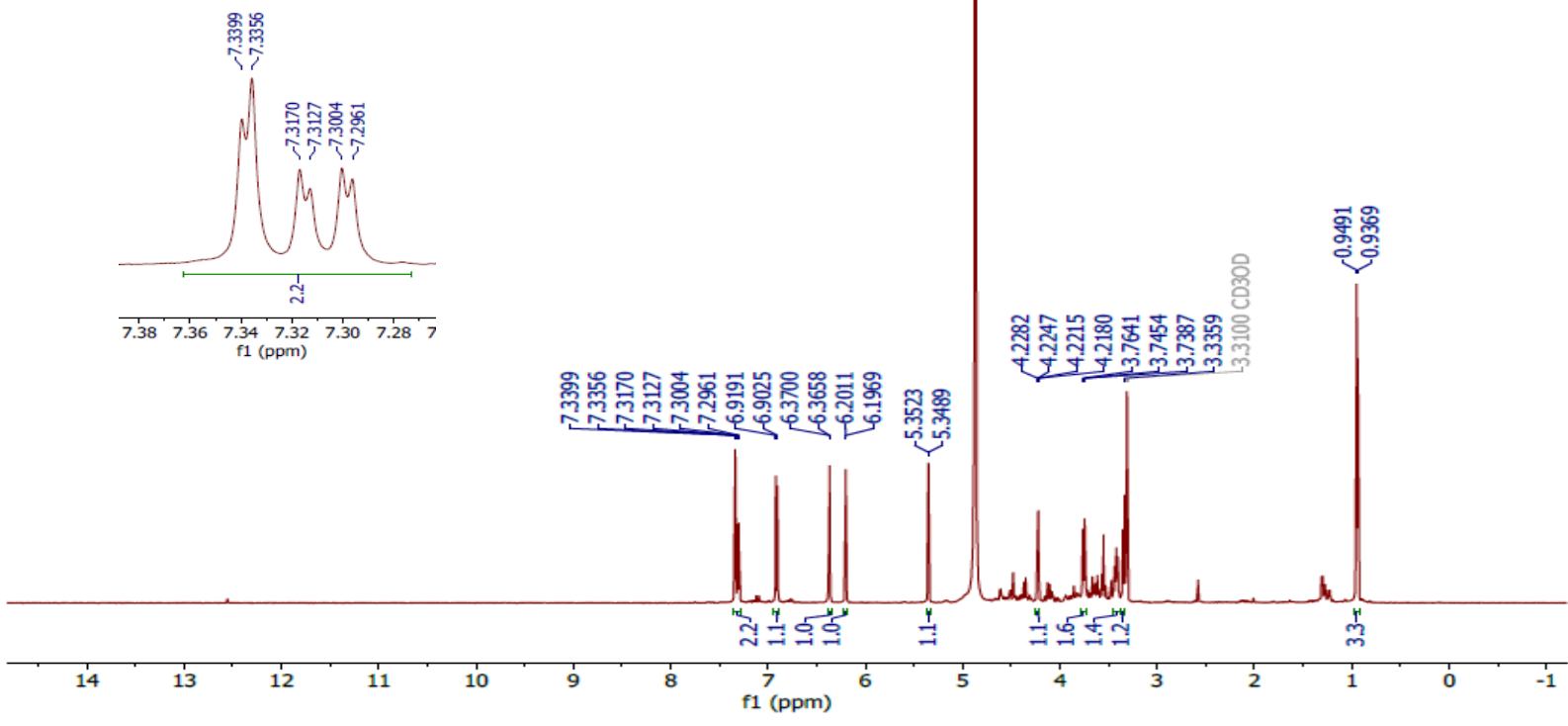

Figure 2. ${ }^{1} \mathrm{H}-\mathrm{NMR}$ spectra of isolate.

The chemical shift of 7.31-7.33 ppm $(2 \mathrm{H}, \mathrm{t})$ demonstrated a proton bound to C-6 'and C-2', when enlarged, showed a doublet-doublet signal on a chemical shift of $7.31 \mathrm{ppm}(1 \mathrm{H}$, dd). The signal indicated a proton at C-6 ', which was close to the proton at C-5' and C-2'. A chemical shift of $7.33 \mathrm{ppm}(1 \mathrm{H}, \mathrm{d})$ indicated the proton attached to $\mathrm{C}-2$ '.

Fazila-SF_13c

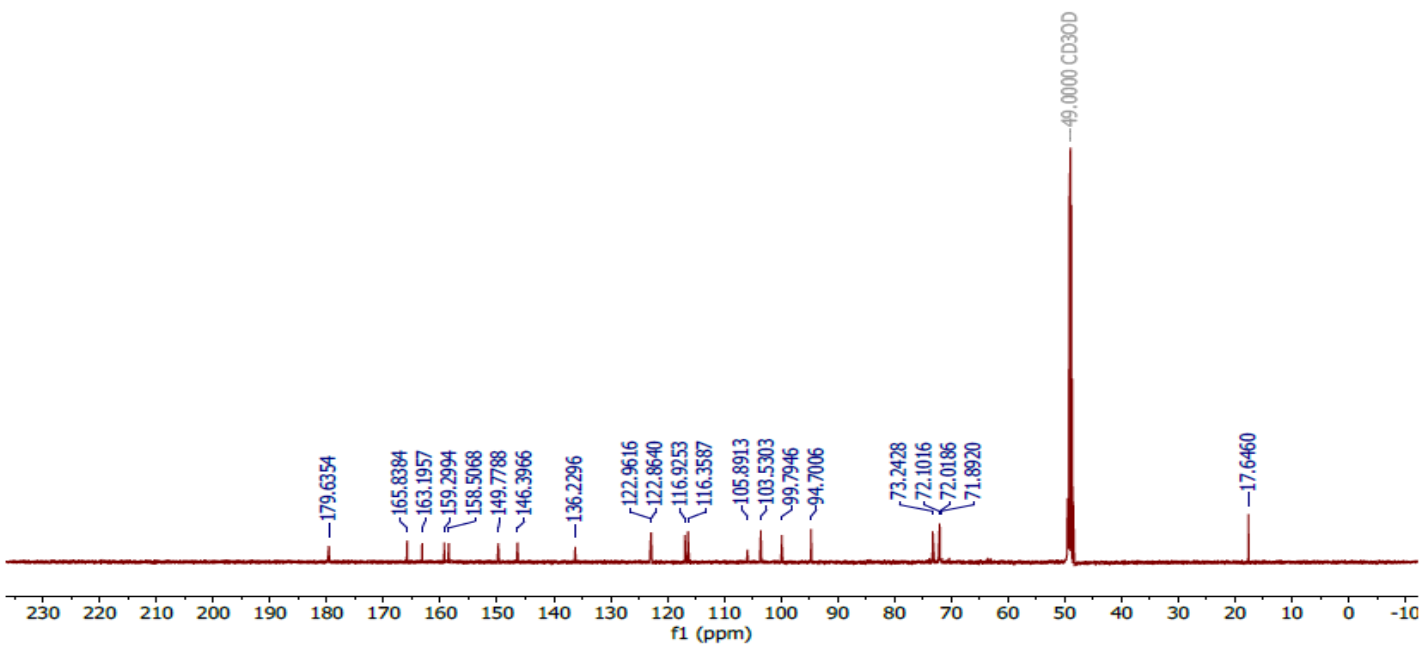

Figure 3. ${ }^{13} \mathrm{C}-\mathrm{NMR}$ spectra of isolate.

${ }^{13} \mathrm{C}-\mathrm{NMR}$ spectral data of the isolate is shown in Figure 3. The chemical shift at 179.6 ppm indicated the presence of a carbon atom in the ketone group (C-4). The chemical shift of 95-170 ppm indicated the presence of carbon atoms in the aromatic moiety. The chemical shift of 71-73 ppm suggested carbon atoms in the sugar group attached to the flavonoid. The chemical shift at $17.6 \mathrm{ppm}$ indicated the presence of a carbon atom attached to three protons (methyl). With the presence of the methyl group, one might suggest that the type of sugar bound 
to this compound is rhamnose. Based on the result of the spectroscopic analysis comparison with literature data, the compound might correspond to Quercitrin (Figure 4) [25].<smiles>O=c1c(OC2(O)[C@@H](O)[C@H](O)[C@H](O)[C@H]2O)c(-c2ccc(O)c(O)c2)oc2cc(O)cc(O)c12</smiles>

Figure 4. Chemical structure of Quercitrin.

Cherng et al. had proposed two types of immunomodulation. Type I works in two ways, namely stimulating Peripheral Blood Mononuclear Cell (PMBC) proliferation and secreting IFN- $\gamma$; and type II works only by secreting IFN- $\gamma$ without causing PMBC proliferation. Flavonoid compounds that stimulate type I immunomodulation include quercetin, while rutin represents a substance that works on type II. Sugar groups in rutin have been suggested to be the main point of differences in immunomodulating responses in type I and type II, in which flavonoid was bound to sugar group [26]. This indicates flavonoid obtained work on type II immunomodulation. Quercitrin meets the criteria of a flavonoid compound bound to sugar, as characterized by black spots under $366 \mathrm{~nm}$ UV light [27].

Quercitrin has several biological activities, including antioxidant, inhibition of thrombogenesis, antiplatelet, increasing lipid metabolism, and inducing hepatic steatosis [2829]. Ethanol extract from the leaves of Houttuynia cordata contains flavonoid compounds Quercitrin and quercetin with antiviral activity (anti-DENV-2) [30]. The potential immunostimulatory activity of the isolate obtained in the present study might be in line with this data.

\section{Conclusions}

Results of this study indicate that $96 \%$ ethanol extract of kabau fruit peel is potential as immunostimulant at a dose of $100 \mathrm{mg} / \mathrm{kg} \mathrm{BW}$, and one of the active compounds is quercitrin.

\section{Funding}

This research was partly funded by the School of Pharmacy, Bandung Institute of Technology.

\section{Acknowledgments}

The authors wish to thank the support of the Department of Pharmaceutical Biology and Department of Pharmacology-Clinical Pharmacy, School of Pharmacy, Bandung Institute of Technology, Bandung, Indonesia.

\section{Conflicts of Interest}

The authors declare no conflict of interest.

\section{References}

1. Kumar, D.; Arya, V.; Kaur, R.; Bhat, Z.A.; Gupta, V. K.; Kumar, V. A review of immunomodulators in the https://biointerfaceresearch.com/ 
Indian traditional health care system. J. Microbiol. Immunol. Infect 2012, 45, 165-184, https://doi.org/10.1016/j.jmii.2011.09.030.

2. Gertsch, J.; Viveros-Paredes, J. M.; Taylor, P. Plant immunostimulants - Scientific paradigm or myth?. J. Ethnopharmacol 2011, 136, 385-391, https://doi.org/10.1016/j.jep.2010.06.044.

3. Behl, T.; Kumar, K.; Brisc, C.; Rus, M.; Nistor-Cseppento, D.C.; Bustea, C.; Anca, R.; Aron, C.; Pantis, C.; Zengin, G.; Sehgal, A.; Kaur, R.; Kumar, A.; Arora, S.; Setia, D.; Chandel, D.; Bungau, S. Biomedicine \& Pharmacotherapy Exploring the multifocal role of phytochemicals as immunomodulators. Biomed. Pharmacother 2021, 133, 1-18, https://doi.org/10.1016/j.biopha.2020.110959.

4. Sujono, T.A.; Dian Kusumowati, I.T.; Munawaroh, R. Immunomodulatory Activity of Muntingia Calabura L. Fruits Using Carbon Clearance Assay and Their Total Flavonoid and Phenolic Contents. Asian J. Pharm. Clin. Res 2020, 13, 140-145, https://doi.org/10.22159/ajpcr.2020.v13i2.36449.

5. Rahmawati, F.; Kurniati, L.; Maria, B. Antioxidant potential and identification of active compounds on Kabau seed (Archidendron bubalinum) flesh and husk extract. J. Sci. Appl. Chem 2020, 23, 83-88, https://doi.org/10.14710/jksa.23.3.83-88.

6. Chen, X.; Tang, R.; Liu, T.; Dai, W.; Liu, Q.; Gong, G.; Song, S.; Hu, M.; Huang, L.; Wang, Z. Physicochemical properties, antioxidant activity and immunological effects in vitro of polysaccharides from Schisandra sphenanthera and Schisandra chinensis. Int. J. Biol. Macromol 2019, 131, 744-751, https://doi.org/10.1016/j.ijbiomac.2019.03.129.

7. Apostolova, E.; Lukova, P.; Baldzhieva, A.; Katsarov, P.; Nikolova, M.; Iliev, I.; Peychev, L.; Trica, B.; Oancea, F.; Delattre, C.; Kokova, V.A Review: Immunomodulatory and Anti-Inflammatory Effects of Fucoidan. Polymers 2020, 12, 2338, 1-22, https://doi.org/10.3390/polym12102338.

8. Liu, S.; Wang, L.; Ren, Q.; Wang, J.; Li, Y.; Wang, G.; Gao, H.; Du, R.; Qin, W. Immunomodulatory and Antioxidant Activities of a Polysaccharide from Ligustrum vicaryi L. Fruit. JEBCAM 2020, 1-10, https://doi.org/10.1155/2020/5431350.

9. Ilina, T.; Skowrońska, W.; Kashpur, N.; Granica, S.; Bazylko, A.; Kovalyova, A.; Goryacha, O.; Koshovyi, O. Immunomodulatory Activity and Phytochemical Profile of Infusions from Cleavers Herb. Molecules 2020, 25, 3721, 1-14, https://doi.org/10.3390/molecules25163721.

10. Marefati, N.; Ghorani, V.; Shakeri, F.; Boskabady, M.; Kianian, F.; Rezaee, R.; Boskabady, M.H. A review of anti-inflammatory, antioxidant, and immunomodulatory effects of Allium cepa and its main constituents. Pharm. Biol 2021, 59, 287-302, https://doi.org/10.1080/13880209.2021.1874028.

11. Shakoor, H.; Feehan, J.; Apostolopoulos, V.; Platat, C.; Salem, A. Dhaheri, A.; Ali, H.I., Ismail, L.C.; Bosevski, M.; Stojanovska, L. Immunomodulatory Effects of Dietary Polyphenols. Nutrients 2021, 13, 728, https://doi.org/10.3390/nu13030728.

12. Chahar, M.K.; Sanjaya Kumar, D.S.; Lokesh, T.; Manohara, K.P. In-vivo antioxidant and immunomodulatory activity of mesuol isolated from Mesua ferrea L. seed oil. Int. Immunopharmacol 2012, 13, 386-391, https://doi.org/10.1016/j.intimp.2012.05.006.

13. Lim, T.K. Archidendron bubalinum. In Edible Medicinal And Non-Medicinal Plants. Springer Netherlands, Dordrecht, 2012; 2, 541-543, https://doi.org/10.1007/978-94-007-1764-0_68.

14. Riasari, H.; Fitriansyah, S.N.; Hartati, R.; Anggadiredja, K.; Sukrasno. Comparison of extraction methods, antioxidant activities, total phenol in seeds and seed shells of Kabau (Archidendron bubalinum (Jack) I.C. Nielsen) from Lampung and South Sumatra. Pharmacogn. J 2019, 11, 1278-1284. https://doi.org/10.5530/pj.2019.11.198.

15. Yunitriani, Elya, B., and Noviani, A. Determination of the antioxidant activity of prasman leaf extracts (ayapana triplinervis [vahl]) and the total flavonoid and phenol contents of the most active extracts. Int. J. Appl. Pharm 2020, 12 (1), 107-111. DOI: http://dx.doi.org/10.22159/ijap.2020.v12s1.FF021.

16. Sharma, N.; Kispotta, S.; Mazumder, P. Immunomodulatory and anticancer activity of Bombax ceiba Linn leaf extract. Asian Pac. J. Trop. Biomed 2020, 10, 426-432, https://doi.org/10.4103/2221-1691.290134.

17. Niu, Y.; Dong, J.; Jiang, H.; Wang, J.; Liu, Z.; Ma, C.; Kang, W. Effects of Polysaccharide from Malus halliana Koehne Flowers in Cyclophosphamide-Induced Immunosuppression and Oxidative Stress on Mice. Oxid. Med. Cell. Longevity 2020, 1-10. https://doi.org/10.1155/2020/1603735.

18. Sati, P.; Dhyani, P.; Bhatt, I.D.; Pandey, A. Journal of Traditional and Complementary Medicine Ginkgo biloba $\mathrm{fl}$ avonoid glycosides in antimicrobial perspective with reference to extraction method. J. of tradit. and Complementary med 2019, 9, 15-23, https://doi.org/10.1016/j.jtcme.2017.10.003.

19. Salvatore, M.M.; Elvetico, A.; Gallo, M.; Salvatore, F.; DellaGreca, M.; Naviglio, D.; Andolfi, A. Applied sciences Fatty Acids from Ganoderma lucidum Spores : Extraction, Identification and Quantification. Appl. 
Sci 2020, 10, 1-12, https://doi.org/10.3390/app10113907.

20. Andayani, D.G.S.; Andini, D.G.T. Utilization of tofu wastewater and sugar industry by-products as a medium for the production of antifungal metabolites by Paecylomyces Marquand StrainTP4. IOP Conf. Ser.: Earth Environ. Sci 2021, 623, 1-8, https://doi.org/10.1088/1755-1315/623/1/012069.

21. Gao, M.R.; Xu, Q.Da, He, Q.; Sun, Q.; Cai, W. A theoretical and experimental study: the influence of different standards on the determination of total phenol content in the Folin - Ciocalteu assay. J. Food Meas. Charact 2019, 13, 1349-1356, https://doi.org/10.1007/s11694-019-00050-6.

22. Chelalba, I.; Abdelkrim, R.; Debbeche, H.; Begaa, S.; Messaoudi, M.; Naima, B. Total phenol and flavonoid content, antioxidant and cytotoxicity assessment of Algerian Launaea glomerata (Cass.) Hook.f. extracts. Eur. J. Biol. Res 2021, 11, 168-176, https://doi.org/10.5281/zenodo.4429705.

23. Bendjeddou, D.; Lalaoui, K.; Satta, D. Immunostimulating activity of the hot water-soluble polysaccharide extracts of Anacyclus pyrethrum, Alpinia galanga and Citrullus colocynthis. J. Ethnopharmacol 2003, 88, 155-160, https://doi.org/10.1016/S0378-8741(03)00226-5.

24. Zalizar, L. Flavonoids of Phylanthus Niruri as Immunomodulators A Prospect to Animal Disease Control. ARPN J. of sci and technol 2013, 3, 529-532.

25. Atun, S.; Arianingrum, R.; Cahyaningsih, L.; Pratiwi, F.A.; Kusumaningrum, R.; Khairuddean, M. Formulation and characterization of Quercitrin nanoelmulsion isolated from Dendropthoe falcata and its antioxidant activity test. Rasayan J. Chem 2020, 13, 1347-1356.

26. Cherng, J.M.; Chiang, W.; Chiang, L.C. Immunomodulatory activities of common vegetables and spices of Umbelliferae and its related coumarins and flavonoids. Food Chem 2008, 106, 944-950, https://doi.org/10.1016/j.foodchem.2007.07.005.

27. Harborne, J.B. Phytochemical methods, Chapman and Hall, London. 1973. https://doi.org/10.1007/978-94009-5921-7.

28. Hur, H.J.; Jeong, Y.; Lee, S.H.; Sung, M.J. Quercitrin Ameliorates Hyperlipidemia and Hepatic Steatosis in Ovariectomized Mice. Life 2020, 10, 243, 1-9, https://doi.org/10.3390/life10100243. .

29. Woo, T.; Ju, H.; Jeon, J.; Kim, K. Quercitrin inhibits platelet activation in arterial thrombosis. Phytomedicine 2021, 80, 1-12, https://doi.org/10.1016/j.phymed.2020.153363.

30. Chiow, K.H.; Phoon, M.C.; Putti, T.; Tan, B.K.H.; Chow, V.T. Evaluation of antiviral activities of Houttuynia cordata Thunb. extract, quercetin, quercetrin and cinanserin on murine coronavirus and dengue virus infection. Asian Pac. J. Trop. Med 2016, 4 , https://doi.org/http://dx.doi.org/10.1016/j.apjtm.2015.12.002. 